\title{
Dismantling Turkey: The Will of the People?
}

\section{Nur Bilge Criss}

To cite this article: Nur Bilge Criss (2010) Dismantling Turkey: The Will of the People?, Turkish Studies, 11:1, 45-58, DOI: 10.1080/14683841003747021

To link to this article: http://dx.doi.org/10.1080/14683841003747021

曲 Published online: 10 May 2010.

Submit your article to this journal

Џ Article views: 501

Q View related articles $\sqsubset$

47 Citing articles: 8 View citing articles 지 


\title{
Dismantling Turkey: The Will of the People?
}

\author{
NUR BILLGE CRISS \\ Department of International Relations, Bilkent University, Bilkent, Ankara
}

\begin{abstract}
The Islamization of Turkey has been an ongoing process since the 1970s and was exacerbated by the 1980 military coup. The Turkish-Islamic synthesis had been conceived as an antidote against communism and became a salient policy. The atmosphere became increasingly convenient for Islamists to participate in politics as well as in socioeconomic forums. The ruling AKP defines itself as conservative democratic. Tariqats have been educating young cadres to fulfill the Islamization mission. Prime Minister Erdoğan monopolizes foreign relations, which result in diplomatic scandals and cause people to ask whether Turkey is changing direction. Counterbalancing forces remain confrontational. Paradigm shifts in practicing politics are sorely needed.
\end{abstract}

Since the promulgation of the Republic, Turkey's Grand National Assembly meeting hall carries the maxim "Sovereignty Belongs to the People-Unconditionally and without Reservation" on its wall. Fifty years hence, from the 1970s onward, some radical parliamentarians who belonged to the myriad religiously-oriented parties that Necmettin Erbakan established voiced a different motto, that "Sovereignty Belongs to God." Erbakan's parties, however, were never able to change the previous maxim. These parties were periodically closed on orders of the Constitutional Court for attempting to change the regime into an Islamic state. ${ }^{1}$

In 2001, a group of younger "reformists" from Erbakan's entourage split from the "traditionalists" and formed the Justice and Development Party (Adalet ve Kalkınma Partisi, AKP). Nobody from the AKP suggests publicly that sovereignty belongs to God. Instead, the AKP's leaders, along with their families, pose as role models, use material incentives to attract adherents, confine civilian bureaucratic promotions to Islamists, and rely on numerous but strong tariqats ${ }^{2}$ to spread the "Islamic way of life" in society. This social endeavor, among other means-political, economic, and financial-is called conservative democracy in the AKP's parlance. Social policy is primarily based on charitable acts whereby government aid is distributed to the poor in kind as well as in cash.

Since 2002, AKP is not only the majority party in the parliament, but it also employs a majoritarian discourse by dwelling on the will of the majority of the

Correspondence Address: Nur Bilge Criss, Department of International Relations, Bilkent University, TR06800, Bilkent, Ankara. Email: criss@bilkent.edu.tr 
Turkish people (in the 2007 national elections, the AKP won by 46 percent of the votes, although this number receded to 36 percent in the local elections of 2009). Either way, the majority in the AKP's sense of the term ignores the 53 percent who did not vote for them. Secondly, contemporary democracies are consensual, not majoritarian. The AKP's position is rather peculiar for a party that claims to want European Union (EU) membership for Turkey. Moreover, the AKP's leader, Recep Tayyip Erdoğan, displays autocratic behavior as prime minister, in speech and attitude towards whomever is critical of policies or the state of the economy. Last but not least is the conceptual confusion that surrounds the AKP's and its leader's true identity. Erdoğan defines himself with religious reference points in his personal worldview and as economically liberal and communitarian-liberal, and as a conservative democrat at the political level. He totally rejects the term "Muslim democrat." The Financial Times quoted Erdoğan as saying, in 2004:

Let me be quite open and clear in stating a fact—we don't find it appropriate to mix religion and politics.... We are not Muslim democrats, we are conservative democrats. Some in the West portray us as [Muslim democrats] but our notion of conservative democracy is to attach ourselves to the customs and the traditions and the values of our society, which is based on family. This is a democratic issue, not a religious one. ${ }^{3}$

The terms are confusing because a conservative stance about family values is a personal as well as a political choice, especially in a patriarchal society like Turkey. It has nothing to do with democratic outlook. Haphazard notions at the highest level of government do not help confidence-building among the opposition or between state institutions.

Populist approaches to foreign relations further raise questions about Turkey's international identity. Counterbalancing forces, mainly the opposition parties, are not acting responsibly either. The culture of political opposition in Turkey has always been confrontational and bitter instead of constructive. The result is polarization between the secularists and government because the political agenda is filled with irrelevant issues. Political scientist Fuat Keyman urges a paradigm shift in politics because both the government and opposition are captive to their own paradigms. As Keyman noted: "Instead of working to solve real problems, Turkey's political agenda is filled with futile debates regarding military coups and military jurisdiction, government versus military, and government versus opposition."4

What is of concern for the purposes of this study is not the Islamization of Turkey under the AKP per se but the Arabization of Turkey. This is done through switching cultural norms, control of women's attire in the name of religion, and new architecture styled after arabesque aesthetics for the conservative nouveau riche. More important, perhaps, is the shift in foreign relations, where the government is blatantly taking sides with Islamists.

The first part of this study dwells on the changing domestic and world conjunctures since the 1980s, which accelerated the AKP's freedom of movement once elected by 
deliberate moves to radically alter the social texture and value systems. Further, the AKP's challenge toward altering checks and balances at the political level is discussed. The second part discusses the Fethullah Gülen Movement (FGM), which works as a global Muslim missionary system and so far seems to back the AKP domestically. The third part focuses on diplomatic scandals that have been tainting the country's prestige at the international level and departure from the traditional Republican code of conduct. The article concludes that such behavior was not exactly what the Turks or the international community expected of AKP rule. Instead, people expected that a majority party rule would lead Turkey to good governance, as the government would not be hampered by bickering coalition partners, provided, and as promised, that the ruling party seeks consensus. Populist and chauvinistic approaches to politics, domestic and foreign alike, killed that expectation in many quarters.

In 2006, this author wrote:

Both international and domestic systemic changes (defined as globalization and integration to the EU) may (but not necessarily) be in the process of transforming the AKP to become a mainstream "conservative democrat" party just as it defined itself in its government program. ${ }^{5}$ AKP's claim to mainstream politics was received with suspicion in many quarters, given that its leaders had been involved in political Islam in the past. The current conjuncture presents an invaluable opportunity to AKP to institutionalize for longevity and entrench itself as a right of center party. However, it has become yet another "leader's party" just like many other Turkish parties which were reduced to obscurity once the leader was gone.... AKP's representative profile affects foreign relations...the AKP leadership reverts to its narrow worldview upon occasion, confusing legality, legitimacy, and personal piety. Although such behavior does not affect foreign/ security policy directly, it none the less presents difficulties in representation as well as image, both of which are significant components of foreign relations. ${ }^{6}$

During the interim, AKP leaders, plausibly encouraged by the 46 percent of the national vote they received in the 2007 elections, have accelerated dismantling the Republic's code of conduct in statecraft—in the name of populism. However, the AKP did not just happen upon Turkey. Its rise was the culmination of the defensive reflex against any shade or dose of the left by the establishment since the 1950s through the promotion of tariqats and religious orientation as an antidote against socialism. This trend was already named the Turkish-Islamic synthesis in the 1970s. In an ironic way, Erbakan's numerous parties as well as AKP are collateral damages of the Cold War in Turkey. It is well worth treading briefly the sociopolitical path in Turkey's contemporary history to recall how the rise of the AKP became probable.

\section{Religion and Politics}

Starting in the 1950s, some older tariqats like the Naqshibandi and a relatively new one, Nurculuk, based on the teachings of Said Nursi, increasingly became power 
bases of mainstream rightist political parties. There seemed to be a tacit understanding between tariqats and the Republican decision-making elite that as long as the former remained behind the political scene, they would even serve as useful in sustaining the status quo against any challenge from the left. It was not a coincidence that Erbakan's first Islamist party was formed one year before the 1971 military coup. It was noteworthy that Air Force General Muhsin Batur was sent to Switzerland, where Erbakan had taken shelter, to convince him to return to Turkey. ${ }^{7}$ Political Islam was empowered especially after the 1980 military coup, though the Islamists are not a homogenous body because they tend to split into many communities. These communities have powerful socioeconomic networks ${ }^{8}$ and are hierarchical, usually with a hoca (preacher) as their leader.

Tariqats also cultivated women, albeit separately from men, and as such created a stratum of Islamist women. Women thus began to address socioeconomic and political problems within the framework of religion. Imam and preacher high schools became a venue through which many Islamist women qualified to study at universities. They were now in the public sphere and soon began to demand positions in public service. Then, debate over wearing the türban at universities erupted in 20032004. Both Turkey's Constitutional Court and the European Court of Human Rights (ECHR) ruled that religious symbols in the public service sphere were against the principle of secularism. Then Foreign Minister Abdullah Gül and his wife Hayrinüssa Gül also brought the State of Turkey to court at the ECHR because she had not been allowed to register at university while wearing a türban. The couple withdrew their case when the ECHR upheld the ruling of Turkey's Constitutional Court in other cases. While this conduct may be interpreted as an act of dismantling, it may also shed some light as to why Gül's presidential candidacy became so controversial.

The AKP promotes Islamist women's political activism at the grassroots. At the same time, out of the 49 female parliamentarians, 30 are from the AKP, including the female minister of education. In short, the Islamization of women is a very important strategy on the road to Islamization of society. ${ }^{9}$ Among political parties in Turkey, the AKP is the only one which has women's commissions organized nationwide.

Turkish-Islamic synthesis became state policy in the aftermath of the September 12, 1980 coup. The understanding or accommodation between the generals of 1980 and the Islamists made strange bedfellows and deepened the rift between secularists and Islamists at all levels of the state apparatus as well as society. It is plausible that this Janus-like system was employed to coopt the Islamists into the mainstream and provide space for them in the management of the country. The Nationalist Action Party (Milliyetçi Hareket Partisi, MHP) has always been close to tariqats. Even the Republican People's Party (Cumhuriyet Halk Partisi, CHP) has been vacillating in its discourse in catering to "Islamic values." Since 1980, Islamists professionally entrenched themselves in all state institutions. Hence, theirs is not a frontal attack but a siege policy to employ Islamist cadres in state institutions, dismantle checks and balances, a sine qua non in democracies, and finally transform Turkey into an 
Islamic republic. When people speak of coups d'etat in Turkey they invariably refer to the military kind of coups. However, civilian coups, in the name of further democratization, remain a serious challenge. ${ }^{10}$ Dismantling operations take time, and the Islamists probably think that time is on their side.

The election of Abdullah Gül, an ardent Islamist, as president was one of the first coups against the principle of checks and balances. As of 2009, both the chief executive (the prime minister) and the president were members of the AKP. The president holds significant powers in appointing members of the Constitutional Court, university rectors, chief justices, and director of the Higher Education Council. ${ }^{11}$ Even in coalition governments political parties vie for the ministries of justice and interior, which has serious implications for controlling the domestic security apparatus as well as the justice system. More often than not, such control becomes a viable tool to be used against the opposition. This was exactly the method used by communists in Central and Eastern Europe in 1945-1946 to transform Poland, Czechoslovakia, and Bulgaria into communist states. Whether a single political party, though in the majority, can successfully impose regime change in Turkey is very doubtful. That process would require dictatorial powers coupled with serious support from abroad. In the short and medium terms neither option is feasible. Nonetheless, the prime minister resorts to waging financial punishment on the Doğan media group for alleged tax evasion, seemingly because Doğan newspapers are critical of his performance. The prime minister asks publicly that people boycott these newspapers. He has no tolerance for caricatures or satire and often takes writers or caricaturists to court. Furthermore, he can be verbally abusive of common people as well as journalists. Perhaps all these reactions stem from the prime minister's populist and direct style as well as an extremely emotional temperament. However, nowhere in the world would the following episode cause such controversy had there been confidence in the AKP's leader.

At the end of June 2009, the prime minister was a guest at the commemoration ceremony of the police force where he stated that the police were the protectors of the regime. While some opinion-makers thought there was nothing wrong with this utterance, others, who were conscious of regimes protected by police enforcement, reacted negatively. ${ }^{12}$ The internal security forces have not been institutionalized professionally and are dominated by pro-Fethullah cadres. In sum, normalization of democracy and elite consensus is still lacking in an environment where the government, armed forces, political parties, judiciary, intellectuals, and universities are split between the forces of dissonance, means of service to the country, or to an omnipresent and omnipotent entity. This brings us to the powerful and global Muslim missionary movement headed by a former preacher, Fethullah Gülen. The disciples of Fethullah became an important source of dissonance on the path to the Islamization of Turkish society. Their impact is not only being observed in Turkey but as a global movement; at least some countries are beginning to question the mission where Fethullah schools have spread. On the contrary, a European sociologist may view the FGM only as a socioreligious formation, intent on helping Muslim Turkish communities to integrate in Europe. ${ }^{13}$ 


\section{The Fethullah Gülen Movement: A Fifth Column or a Humanitarian Mission?}

There are two major but complementary viewpoints about the movement. One is a sociological academic approach that tries to understand the FGM phenomenon but invariably points to the fact that this is a struggle to control the public sphere. ${ }^{14}$ The other approach evaluates the FGM from a political perspective based on preparing cadres to take over the state institutions as well as serving international Islamism. ${ }^{15}$

"What are Gülen's intentions?" asked Rachel Sharon-Krespin in an incisive article. ${ }^{16}$ Secular conglomerates have had a dominant position in Turkey.

Never before, though, has a single individual started a movement that seeks to transform Turkish society so fundamentally. Gülen now wields a vocal partisan media; a vast network of loyal bureaucrats; partisan universities and academia; partisan prosecutors and judges; partisan security and intelligence agencies; partisan capitalists, business associations; NGOs, and labor unions; and partisan teachers, doctors, and hospitals. ${ }^{17}$

Gülen's ultimate objective can be found in his sermons of 1999 when some Turkish TV channels aired the video clips. There he cautioned his followers to wait until the time is ripe to make a forward move; otherwise, they would be crushed like in Algiers, Syria, and Egypt. Meanwhile, adherents were told to "move in the arteries of the system without anyone noticing [their] existence until [they] reach all the power centers." 18 However, it is impossible not to notice.

Male doctors who refuse to treat women and female doctors who refuse to treat men, university students who cannot look at a female academician in the eye, fine arts students who refuse to study nude bodies, medical students who do not attend anatomy classes, mayors who remove statues and statuettes from public parks or close down girls' volleyball teams, governors who preach gender-segregated schools, and medical doctors who appear on TV shows and declare that cancer can be cured by faith, are very forthcoming. Members of tariqats no longer employ dissimulation.

It is not clear how many Gülen schools there are, in Turkey or abroad, because other schools are supplied with adherents through cramming schools into national university entrance exams, free housing for poor students (Işlkevleri, or lighthouses). FGM owns television stations in Turkey (Samanyolu TV) and in the United States (Ebru TV and Mehtap TV). The movement is sponsored by "conservative" businessmen of the Turkish Industrialists Confederation. FGM owns an interest-free bank, Asya Finans (Asia Finance). Fatih University in Istanbul and Virginia International University in the United States are cited among the FGM-owned universities. ${ }^{19}$ Fethullah Gülen lives in Pennsylvania, where he first settled for the purpose of medical treatment for diabetes, and he recently obtained permanent residency status. What is surprising is that the US court did not even question the false pretense of diabetes, which is a treatable disease almost everywhere around the world, including in Turkey. In reality, Gülen found political asylum in the United 
States by fleeing a pending court case. Turkey's Supreme Court upheld his acquittal in 2008, but he remains in self-exile. ${ }^{20}$ The verdict conveniently removed the accusation made by the top prosecutor against President Gül during debates in the Constitutional Court about closing down the AKP. Gül was accused of sending directives to all Turkish embassies abroad, when he was Minister of Foreign Affairs, to cultivate good relations with FGM schools around the world.

Here in the US the FGC [Fethullah Gülen Community] runs over 90 charter public schools in at least 20 states.... Indeed, the fact that so little has been written about the FGC schools here in the US, as well as the accolades that have been accorded the FGC as a model of "moderation" by some in our government would appear to confirm that the FGC and its schools are doing an excellent job of heading Gulen's exhortation ["move in the system without anyone noticing your existence until you reach all the power centers..."] and masking their true intent. ${ }^{21}$

The message of tolerance and interfaith dialogue that FGM transmits is made for international consumption at this conjuncture where the West, and especially the US, is keen on promoting "friends of Muslims" image in the fight against international terrorism. Sharon-Krespin concludes:

What Turkey's Islamists really want is to remove the founding principles of the Turkish Republic. So long as US and Western officials fail to recognize that Gülen's rhetoric of tolerance is only skin-deep, they may be setting the stage for a dialogue, albeit not of religious tolerance, but rather to find an answer to the question, "Who lost Turkey?" 22

Dismantling operations, just like in the case of terrorism, require international support. This may be an interesting case study onto itself. Suffice it to say that FGM power projection towards Turks in the US may be one thing, but if that projection is extended to other American Muslims, that will be an entirely different story. The main concern in FGM is not the state of Islam but the establishment of an Islamic state. It is noteworthy, however, that in the fourteenth century one of the greatest Muslim philosophers, Ibn al-Khaldun, had argued that there had not been an Islamic state after the Muhammad and the four caliphs. Other Muslim state formations were territorial, dynastic, and were based on power politics, not on religion. ${ }^{23}$

At this point in time, FGM represents a struggle to control the public sphere, mainly through women's minds and bodies, because this is the most visible venue. Marriage patterns in the community are also between members and are dictated by the older brothers and sisters in charge of groups. There are indeed some young women who voluntarily begin wearing the türban, mainly for psychological reasons, piety, and respectability. However, many are forced into it by their male relatives or in FGM communities as small children. Female dermatologists and orthopedists tell horror stories of little girls clad in different styles of hijab. Skin and bone ailments 
are common in growing female children. ${ }^{24}$ This situation cannot be explained as freedom of choice or human rights. Iranian-French writer Djavann wrote that:

it is inappropriate to probe the motivations of every young girl wearing the veil when what is at stake is a political agenda.... Islam can exist without the veil, but the Islamist system cannot, because the veil is the symbol, the flag and the keystone of the Islamist system. ${ }^{25}$

Even if one looks at FGM only as a social phenomenon, it still appears as a social engineering design. It may be akin to the Protestant missionary movement of the nineteenth century, yet the latter had no claim on state power. FGM's humanitarian discourse and activities and its emphasis on tolerance and interfaith dialogue seem innocent. However, there is no question about its impact on the Islamization of the Turkish society. This resonates on the relationship between the ruling party and secularists. According to a reliable public opinion pollster, the number of people who do not trust the AKP government is on the increase. ${ }^{26}$ The AKP leadership, based on its majoritarian hubris, has done nothing to dispel suspicions even though some suspicions may be based on conspiracy theory. David Ghanim wrote:

It [AKP] is the first experience that considers the heritage of the past to be no hinderance to a positive engagement with the future. In power, the AKP has proven, so far at any rate, that there is no hidden agenda to Islamize Turkish society. Rather, they are investing in solving concrete socioeconomic and political problems. ${ }^{27}$

Parallel to Ghanim, Y1lmaz argued that allowing space to Islamists in politics is a sure measure to prevent radicalization. ${ }^{28}$ On the contrary, Bassam Tibi wrote:

Too many in the West praise the AKP as " moderate Islamic." The only difference, however, between moderate and jihadist Islamists is the use of the ballot box instead of violence to come to power. It may be important to include Islamists in democracy but certainly not with the Western naive notion that inclusion will tame Islamism. ${ }^{29}$

Essentially, the AKP does not need an agenda of Islamization; FGM and tariqats are already doing the work. In sum, between the tariqats, FGM, and the government not only is Turkey's social texture is dismantled, the traditional diplomatic code of conduct and statecraft are also upset. This is reflected in the international relations format through diplomatic scandals (discussed below) caused by the leaders' behavior.

\section{Populist Approaches to Foreign Relations}

Between 2003 and 2008, many op-eds, policy papers, and scholarly articles were written about the strenous relations between Turkey and the United States because 
the Ankara parliament did not pass the resolution to accommodate American troops on Turkish territory for the purpose of a northern attack on Iraq. All the literature dwelled on strategy, tactics, political implications, and the bitterness this incident caused in relations. This study assesses the situation from a diplomatic point of view.

In 2002, before Erdoğan held portfolio as prime minister he made encouraging but premature promises to President George W. Bush during a visit to the White House about US troop deployments on Turkey's territory to facilitate America's impending war on Iraq. This backfired, to the detriment of relations between the two countries. While Erdoğan may have relied on the AKP's majority in the parliament, he was ignorant of historical precedence. Despite alliances, the Republican state had never become a conduit for war against any neighbor, unless an operation was clearly undertaken under the auspices of the United Nations, as had been the case in the Gulf War of 1991.

The resolution to allow US troop deployment in Turkey was rejected by a thin margin in parliament on March 1, 2003. Out of the 533 members of parliament who voted, 250 voted against, 264 in favor, and 19 were undecided. Bülent Arınç, speaker of parliament, resorted to Article 96 of the Constitution, which called for the absolute majority of votes by those present. According to simple calculation, absolute majority had to be 266 , but the yes votes were two short of the required number. None of the members of parliament, who voted affirmatively out of partisan loyalty to the leader, opposed Arınç.

The "failure" to pass the bill resulted in recriminatory and at times a vituperative response from the US. ${ }^{30}$ Plausibly, in his enthusiasm to be accepted by Turkey's strongest ally, Erdoğan managed to cause a diplomatic scandal by misleading Washington. Nescience, combined with misplaced advice, was very costly to the credibility and respectability of the state. However, this point was lost during the heat of war.

In November 2005, concluding a state visit to Copenhagen, Erdoğan and Danish Prime Minister Anders Fogh Rasmussen were scheduled to hold a press conference. Having noticed that pro-PKK (Kurdistan Workers' Party) Roj TV was present, Erdoğan walked out in protest, thus embarrassing his host as well as becoming a target of criticism in Europe about intolerance towards an accredited communications agency. ${ }^{31}$ This would not be the only negative encounter between Erdoğan and Rasmussen.

As time went by, Erdoğan became totally convinced that people in Turkey liked his bullying behavior as a tough man of the people. That should not be taken for granted when put against the test of Turkey's image and prestige, concepts taught in courses on foreign relations to be among the most cherished principles of national interest and foreign policy conduct. However, perhaps "national interest" is redundant in this context, considering that worldviews are based on the community of Muslims, not on the nation per se.

Islamization of international behavior also increased. In July 2008, the AKP government hosted Sudan's president, Omar al-Bashir, the "butcher of Sudan," during the African summit. It did not seem to bother the leadership that Bashir was 
being held responsible for the massacre of 200,000 of non-Arab Africans ${ }^{32}$ as well as 3 million people who fled their homes. Investment opportunities on Sudanese oil had priority.

When King Abdullah ibn Abd al-Aziz al-Saud visited Turkey in November 2008 , it was only normal to extend royal protocol. However, both the president and prime minister paid him the first visit at Swiss Hotel in Ankara when diplomatic protocol calls for it to be the other way around. When criticized that this was not the proper state conduct, Gül and Erdoğan stated that they did this out of respect for the elderly king. ${ }^{33}$ It is not clear whether the king returned the visit; he practically held court at the hotel. In 2007, during the king's prior visit, the feminist Flying Broom news site had criticized AKP leadership of extending him royal protocol under the headline, "The King from the Country where Women are Nonentities Was in Turkey." 34

On March 2, 2009, the Davos World Economic Forum scandal followed in the aftermath of the Gaza war. At this venue, the very same Erdoğan who had piously respected old age in the case of the Saudi king shouted insults at Israel's President Shimon Peres, who is just as venerable. Erdoğan walked out of the televised meeting in anger, vowing never to return to Davos. It took just one week for Arab countries like Saudi Arabia, Jordan, and Egypt to publicly announce through their foreign ministers that third parties should keep out of the process of normalization between Arabs and Israel. ${ }^{35}$

The last, but not least, of the diplomatic scandals revolved around Anders Fogh Rasmussen's candidacy as NATO general secretary. In April 2009, and in total defiance of the Alliance, Turkey's prime minister threatened to veto Rasmussen, who was supported by the EU and United States. Erdoğan's unfavorable attitude towards Rasmussen was based on the fact that he had not apologized for some caricatures in a Danish newspaper allegedly insulting Muhammad, as well as for not having done anything about the pro-PKK Roj TV. ${ }^{36}$ For the Danish prime minister, the former issue was about freedom of expression. The latter exceeded his authority and was a matter for the Danish courts. Nonetheless, following a long diplomatic conference call with US President Barack Obama and European leaders, Erdoğan abandoned his show of force but declared that Turkey was given some concessions in both matters. This, of course, was not the case. ${ }^{37}$ An equally significant point was that Erdoğan claimed to have received many calls from Islamic countries urging him to veto Rasmussen. ${ }^{38}$ If that is the case, then one would seriously question whether the prime minister is a spokesman on behalf of the Islamic countries or chief executive of the Republic of Turkey.

In 2007, the AKP defined its foreign policy as proactive. ${ }^{39}$ However, since foreign policy has been monopolized by the prime minister it has become increasingly reactive. Articles written by retired ambassadors urging fine-tuning in foreign policy behavior are to no avail. ${ }^{40}$ In April 2009, a Financial Times editorial advised Turkey's government to keep to calm and quiet diplomacy. It argued that the sharp tone employed in the international arena is not only harmful to the country but is also unwarranted. ${ }^{41}$ 


\section{Conclusions}

Conclusions to be derived from the foregoing are manifold. Starting with the issue of populist approaches to foreign relations, foreign policy analysts increasingly refer to the AKP's foreign policy, not to Turkey's foreign policy. ${ }^{42}$ This is disturbing in more ways than one. In the first place, it raises the question of whether the party and state are viewed as one. If so, the situation has dire consequences for the state of democracy in Turkey. Secondly, it is unrealistic as well as destructive to abandon the traditional codes of conduct and protocol in foreign relations because there is no room for sentimental populism in the international arena. The repercussion is loss of prestige. Third, meeting with radical factions in the Middle East and flaunting this publicly is not conducive to peace-building. ${ }^{43}$ It alienates both the major Arab countries like Egypt, Saudi Arabia, and Jordan as well as Israel. Finally, the Turkish prime minister's sharp tone about the Gaza war and the AKP's active anti-Jewish propaganda had domestic repercussions against Turkish Jews. The billboards put up by the AKP in Istanbul with anti-Semitic slogans, the cartoon exhibit put up in Istanbul's Taksim metro station-the most central artery of the city's public transportation system - and the prime minister's scolding of Peres seriously disturbed the tiny Jewish community of Istanbul. Islamists had definitely blurred the distinction between Turkey's Jews and the state of Israel. Only after public appeals to the prime minister by Jewish organizations in the US and by prominent Turkish-Jewish businessmen did the outrageous discourse and protests calm down. The prime minister vowed to fight anti-Semitism in Turkey. ${ }^{44}$ It remains unclear as to what is being done about this issue.

As for the Islamization of Turkish society under the tariqats and FGM's missionary activities, Islamists may ask what is wrong with their religious teachings and spreading the virtues of an Islamic way of life. The repercussions, however, appear to be instilling political Islamism, Talibanesque worldviews, ${ }^{45}$ and increasing xenophobia, racism, and women-hatred, which go hand in hand with increased social conservatism in Turkey attested to by polls and academic surveys. In July 2007, interviews of 1,715 people conducted by Professor Y1lmaz Esmer in 33 provinces revealed that 29 percent favor the implementation of Shari'a law, including not only curbing women's legal rights but also stoning to death in cases of adultery. ${ }^{46}$ The current substitute for the latter is increased violence against women as well as "honor" killings. It may be of some consolation that percentages on this issue fell from 38 percent in 1999 by a factor of 9 percent in 2007.

Binnaz Toprak's study on social conservatism revealed that while the political and legal systems in Turkey will remain secular, society faced Islamization. This resulted in all forms of pressure and discrimination against secular women, especially outside of the three large cities of Ankara, Istanbul, and Izmir. Another significant point in Toprak's study was that people were forced to behave conservatively in order to be promoted or awarded government contracts. Therefore, what is on the rise is not religiosity but social conservatism. ${ }^{47}$ Another sociopolitical factor in Turkey is that "Others," defined as mainstream republicans and social democrats, 
are caught between liberals, nationalists, and Islamists, who are engaged in a vicious struggle to dominate. ${ }^{48}$

Mustafa Kemal Atatürk, the founder of the Republic, was successful in making a social revolution by changing the value systems of the Ottoman society because he instilled pride in his people. ${ }^{49}$ For Atatürk, statesmanship was a well-studied form of art; leadership was not just about merely being a politician. Attempts to alter the value systems of an entire nation have two major characteristics; moral authority and instilling pride. Otherwise, religiously oriented oppression and worldviews backfire sooner than later. The AKP's identity crisis of late, between Islamism and conservative democracy, will be remembered as a waste of time and energy for Turkey because the chances of being reelected as a majority party are increasingly slim, and Turkey's European vocation is becoming more questionable under the AKP government at a time when there is once again more enthusiasm among the people for membership in the European Union. A major problem with the AKP is that it is trying to be everything to everybody both domestically and internationally, resulting in loss of confidence even in circles that once had confidence in the party. Counterbalancing forces in the ruling party and outside need to be constructively vigilant.

\section{Notes}

1. In 1970, Erbakan formed the National Order Party (NOP), closed by the Constitutional Court in 1971. In 1973, the party was revived as the National Salvation Party (NSP), closed by the Constitutional Court in 1981. Erbakan reestablished it as the Welfare Party (WP) in 1983. As it became clear that this party would be closed by 1998, he formed the Virtue Party in 1997, which lasted until 1999. The last revival of the chain of parties is the Felicity Party (FP), since 2001. See Metin Heper and Nur Bilge Criss, Historical Dictionary of Turkey, $3^{\text {rd }}$ ed. (Lanham, MD: Scarecrow Press, 2009), alphabetical entries.

2. Tariqats are popular religious orders. To reach a mystic union with God, the tariqat requires all members to follow a proscribed behavior as determined by the leader.

3. Quoted by İştar Gözaydın, "Religion, Politics, and the Politics of Religion in Turkey," in Dietrich Jung and Catharina Raudvere (eds.), Religion, Politics and Turkey's EU Accession (New York: Palgrave Macmillan, 2008), pp. 160-176, p. 173.

4. Fuat Keyman, "Yeni Siyaset Gerekliliği" [The Necessity for a New Approach in Politics] Radikal Íki (July 12, 2009), p. 5, newspaper supplement.

5. Adalet ve Kalkınma Partisi Hükümet Programı [AKP Government Program], announced in parliament on March 18, 2008, 59th government, by Prime Minister Erdoğan, http://www.akparti.org.tr (accessed April 27, 2009).

6. This is in reference to Erdoğan's response to riots in France in 2005, which were instigated by North African Muslim émigrés. Accordingly, the cause of riots was the ban on headscarves in state schools. Nur Bilge Criss, "Turkish Foreign and Security Policy with the AKP Government," in Antonio Marquina and Mustafa Aydın (eds.), Turkish Foreign and Security Policy, Its Environs in Eurasia and the Middle East (Madrid: Universidad Compulsente de Madrid, 2006), pp. 23-46, pp. 24-25.

7. Nur Bilge Criss, "Mercenaries of Ideology; Turkey's Terrorism War," in Barry Rubin (ed.), Terrorism and Politics (New York: St. Martin's Press, 1991), pp. 123-150.

8. Uğur Mumcu, Tarikat, Siyaset, Ticaret, 27th ed. [Tariqats, Politics, Trade] (Ankara: um-ag Vakfı Yayınları, 2008).

9. Mustafa Peköz, İslami Cumhuriyete Doğru, Türkiye’de Siyasal İslamın Dünü, Bugünü ve Yarını [Towards an Islamic Republic, the Past, Present and Future of Political Islam in Turkey] (Istanbul: Kalkedon Yayınları, 2009), pp. 119-127; Özlem Tür and Zana Çıtak, “AKP ve Kadın: Teşkilatlanma, Muhafazakârlık ve Türban," [AKP and Women: Organizations, Conservatism and Turban] in İlhan 
Uzgel and Bülent Duru (eds.), AKP Kitabı, Bir Dönüşs̈̈mün Bilançosu [AKP's Story: An Account of Transformation] (Ankara: Phoenix Yayınevi, 2009), pp. 614-629.

10. Altan Öymen, "Demokrasiyle Gelen 'sivil darbe'ciler," [Civilian Coup Makers that Come with Democracy] Radikal (Newspaper) (February 24, 2009), p. 13.

11. Yalçın Bayer, "Yeni üniversitelerde tarikat-cemaat savaşı," [War between Tariqats and Congregation in the Newly Established Universities] Hürriyet (July 29, 2008), available at http://arama.hurriyet. com.tr/arsivnews (accessed May 8, 2009).

12. Nuray Mert, "Rejim'in Koruyucusu Kim?" [Who is the Protector of the Regime?] Radikal (July 2, 2009), p. 10.

13. Jonathan Lacey, "The Gülen Movement in Ireland: Civil Society Engagements of a Turkish Religiocultural Movement," Turkish Studies, Vol.10, No. 2 (June 2009), pp. 295-315.

14. Elisabeth Özdalga, İslamcılığın Türkiye Seyri, Sosyolojik Bir Perspektif [Islamism in Turkey, A Sociological Perspective] (Istanbul: İletişim Yayınları, 2006), p. 235.

15. Hikmet Çetinkaya, Fethullah Gülen'in 40 Ylllk Serüveni [Fethullah Gülen's 40 Year-Long Adventure] (Istanbul: Güniz Yayıncılık, 2004); Nevzat Bölügiray, AKP Değissiyor mu? [Is AKP Changing?] (Istanbul: Tekin Yayınevi, 2004); Hikmet Çetinkaya, Fethullah Gülen, ABD ve AKP [Fethullah Gülen, the USA and AKP] (Istanbul: Güniz Yayıncılık, 2007).

16. Rachel Sharon-Krespin, "Fethullah Gülen's Grand Ambition, Turkey's Islamist Danger," The Middle East Quarterly (Winter 2009), pp. 55-66; 61. Available at http://www.meforum.org/2045 (accessed April 28, 2009).

17. Ibid.

18. Ibid.

19. “Gulen Movement: Turkey's Third Power," Jane's Islamic Affairs Analyst (jiaa.janes.com) (February 2009), pp. 11-14.

20. "Turkish Top Court Approves Sect Leader's Controversial Acquittal," Hürriyet (English) (June 24, 2008), http://arama.hurriyet.com.tr/arsivenews (accessed May 8, 2009).

21. Guy Rodgers, "Fethullah Gulen: Infiltrating the U.S. Through Our Charter Schools?" http:// www.actforamerica.org/index.php, (accessed April 28, 2009). Also includes US Gulen Movement Organizational Chart. Quote inserted for clarification.

22. Sharon-Krespin, "Fethullah Gülen's Grand Ambition, Turkey's Islamist Danger," p.66.

23. Ahmet Arslan, İbn-i Haldun [Ibn al-Khaldun] (Istanbul: Bilgi Üniversitesi Yayınları, 2009).

24. Personal interviews with female physicians in Ankara who wished to remain anonymous, April 2009.

25. N. Maruani, "Reformist Iranian-French Writer Chahdortt Djavann: The Hijab, a Political Weapon and Form of Sexual Abuse, Should be Outlawed," MEMRI (Middle East Media Research Institute), Iran/Reform Project No. 533/July 7, 2009, p. 2 (July 7, 2009).

26. Tarhan Erdem, "Sorunumuz Andıç mı?" (Is the Only Problem a Secret Document?) Radikal (June 15, 2009), p. 10.

27. David Ghanim, "Turkish Democracy and Political Islam," Middle East Policy (Spring 2009), p. 7-8.

28. İhsan Yılmaz, "Muslim Democrats in Turkey and Egypt: Participatory Politics as a Catalyst," Insight Turkey, Vol. 11, No. 2 (2009), pp. 93-112.

29. Bassam Tibi, "Islamists Approach Europe, Turkey's Islamist Danger," Middle East Quarterly, (Winter 2009), pp. 47-54; 51, http://www.meforum.org/2047 (accessed May 5, 2009).

30. See Criss, "Turkish Foreign and Security Policy with the AKP Government."

31. "Financial Times: Erdoğan Rasmussen'i küçük düşürdü," [Financial Times: Erdoğan Embarrassed Rasmussen], Hürriyet (November 18, 2005), http://www.hurriyet.com.tr/goster/haber (accessed July $8,2009)$.

32. Hikmet Çetinkaya, "Darfur Kasabı Türkiye'de," [The Butcher of Darfur is in Turkey] Cumhuriyet, (August 20, 2008); Soner Çağaptay, "Türkiye artık o eski Türkiye değil," [Turkey is No Longer the Same] Newsweek Türkiye, http://www.newsweekturkiye.com (accessed July 10, 2009). Cumhuriyet, http://erdem43.blogcu.com/darfur-kasabi_hitmetcetin_223 (accessed July 10, 2009).

33. Yavuz Çekirge, "Kral Abdullah ziyaretinin perde arkası," [King Abdullah's Visit, Behind the Scenes] Hürriyet (July 8, 2009) http://www.hurriyet.com.tr/satrateji (accessed July 8, 2009). The 
article questions whether the visit was part and parcel of a project to include Turkey in a Sunni front against Iran in the region; "Küstah Kralı kim çağırdı?" [Who Invited the Arrogant King?] Tercüman (July 8, 2009), http://www.tercuman.com.tr (accessed July 8, 2009).

34. H. Miray Vurmay, "Kimliksiz kadınlar ülkesinin kralı Türkiye'deydi," [The King from the Country Where Women are Nonentities was in Turkey] Uçan Süpürge Kadın news site, (December 11, 2007), http://www.ucansupurge.org/arsiv (accessed July 8, 2009).

35. Nilgün Cerrahoğlu, "Arapça Balans Ayarı," [Fine Tuning in Arabic] Cumhuriyet (February 8, 2009), http://www.cumhuriyet.com.tr (accessed June 11, 2009).

36. "Erdoğan: 'Rasmussen'in adaylığına olumsuz bakıyorum," [Erdoğan: I Have a Negative Opinion of Rasmussen's Candidacy] EurActiv news site, http://www.euractiv.com.tr (accessed July 8, 2009).

37. "Rasmussen: Gidip Türklere satılmadım," [Rasmussen: I Did Not Sell Myself to the Turks], Forum Türkiye news site, http://www.forumturkiye.com (accessed July 8, 2009).

38. "İslam ülkelerinin özel isteği," [Special Requests from the Islamic Countries] Habername news site, http://www.habername.com (accessed July 8, 2009).

39. Egemen Bağış, AK Parti-Dış Politikamız Hakkında Sılkça Sorulan Sorular [Frequently Asked Questions about our Foreign Policy] (Ankara: AKP Publication, 2007).

40. Özdem Sanberk, "Gazze krizinden kim kazançlı çıktı?” [Who Benefited from the Gaza Crisis?] Radikal (February 17, 2009), p. 15; Osman Faruk Loğoğlu, "Türk dış politikası: Çok boyutluluk mu, eksen değişikliği mi?" [Turkish Foreign Policy: Is it Multidimensional or Deviated?] Radikal (February 27, 2009), p. 15.

41. “Turkey Should Try Calm and Quiet Diplomacy," Financial Times, (April 12, 2009), p. 2.

42. Soner Çağaptay, "The AKP's Foreign Policy: The Misnomer of 'Neo-Ottomanism,"” The Washington Institute of Near East Policy (April 27, 2009); Soli Özel, "Divining Davutoğlu: Turkey's Foreign Policy Under New Leadership," On Turkey (June 4, 2009), pp. 1-3; On Turkey, "The German Marshall Fund of the United States", www.gmfus/org; M.K. Kaya and Halil M. Karaveli, "Vision or Illusion? Ahmet Davutoğlu's State of Harmony in Regional Relations," East West Studies (June 5, 2009), p. 2 , http://www.eastweststudies.org (accessed July 9, 2009).

43. Barry Rubin, “Turkey's New Foreign Minister and It's Foreign Policy Strategy," Global Research in International Affairs website, http://www.gloria-center.org/Gloria/2009/05/Turkey\%27s-NewForeign-Minister.html (accessed May 3, 2009); Soner Çă̆aptay, "In Love with Arab Islamists," Hurriyet Daily News (May 20, 2009), p. 2.

44. See "Jewish Based Organizations Urge Turkish PM to Address anti-Semitism," Jewish World, January 23, 2009, http://www.1923turk.biz (accessed April 30, 2009); “Turkish Jews Fearful of AntiSemitism after Gaza," Jewish World (January 27, 2009), http://www.ynetnews.com (accessed April 30, 2009); Michael van der Galien, "Jewish Emigration from Turkey to Double," PoliGazette (February 2, 2009), http://www.Poligazette.com/2009/02/02 (accessed April 30, 2009); Emrullah Uslu, “AKP Government's Policies Toward Anti-Semitism May Not be Enough," Eurasia Daily Monitor, Vol. 6, No. 22 (February 3, 2009); "Erdogan Vows to Fight Anti-Semitism in Turkey," The Jerusalem Post (February 3, 2009), http:www.jpost.com (accessed April 30, 2009); Soner Çağaptay, "In the Name of Islam: A Liberal Appeal," Middle East Strategy at Harvard (March 30, 2009), pp. 1-3.

45. Altan Öymen, "Siyasetin ve medyanın yanlışlara 'yanlış' deme görevi” [Politicians and Journalists Bear the Responsibility to Point out Rights and Wrongs] Radikal (June 9, 2009), p. 13, cites a fellow journalist, Nilgün Cerrahoğlu, who coined the term translated into English as Talabanesque worldview.

46. Eser Karakaş, "Prof. Dr. Yılmaz Esmer'in İlginç Araştırması" [Interesting Research by Yılmaz Esmer] Star (August 19, 2007), http://www.cafesiyaset.com/haber/20070819 (accessed September 14, 2009).

47. "Political Power and Social Conservatism in Turkey, Featuring Binnaz Toprak," The Washington Institute for Near East Policy, Policywatch, No. 1529 (June 8, 2009).

48. Haluk Şahin, Liberaller, Ulusalcılar, Islamcilar ve Ötekiler [Liberals, Nationalists, Islamists and the Others] (Istanbul: Say Yayınları, 2008).

49. Amin Maalouf, Çivisi Çıkmış Dünya [Le dérèglement du monde][The World Gone Awry] transl. from the French by Orçun Türkay (Istanbul: Yapı Kredi Yayınları, 2009), p. 50. 